\title{
Heat stress-mediated gene expression in the body wall of the Japanese sea cucumber Apostichopus japonicus
}

\author{
Huan Zhao ${ }^{1,2}$, Hongsheng Yang ${ }^{1, *}$, Heling Zhao ${ }^{1,2}$, Muyan Chen ${ }^{3}$, Shilin Liu ${ }^{1}$ \\ ${ }^{1}$ Key Laboratory of Marine Ecology and Environmental Sciences, Institute of Oceanology, Chinese Academy of Sciences, \\ Qingdao 266071, PR China \\ ${ }^{2}$ Graduate University, Chinese Academy of Sciences, Beijing 100049, PR China \\ ${ }^{3}$ Department of Developmental and Cell Biology, University of California, Irvine, California 92697, USA
}

\begin{abstract}
Suppression subtractive hybridization was used to analyze the differences in gene expression in the body wall of the Japanese sea cucumber Apostichopus japonicus, induced by heat stress $\left(28^{\circ} \mathrm{C}\right)$, in order to understand the response at the molecular level. A total of 737 clones was selected and analyzed, and 165 distinct sequences were obtained, with 65 sharing similarity to sequences in public databases. The sequenced genes were classified into 3 functional categories. Increased expression of some genes in response to stress was concomitant with decreased expression of genes concerned with energy production and metabolism. The results (1) suggest that heat stress has significant effects on gene expression in A. japonicus, and (2) provide the basis for further study of molecular regulation mechanisms underlying the response to heat stress and estivation in A. japonicus.
\end{abstract}

KEY WORDS: Apostichopus japonicus · Body wall · Heat stress · Suppression subtractive hybridization · Stress response

\section{INTRODUCTION}

The Japanese sea cucumber Apostichopus japonicus, a marine poikilotherm found along Asian coasts, has been exploited as an important economic resource in Russia, China, Japan, and Korea (Liao 1997). In response to bottom temperatures $>20^{\circ} \mathrm{C}$, adult $A$. japonicus stop feeding and reduce oxygen consumption rate, entering a dormant state called estivation (Choe 1963, Li et al. 1996, Liu et al. 1996). Earlier studies showed that estivation is temperature-dependent and that $A$. japonicus in the estivation state can be reactivated by culturing at a reduced temperature (Li et al. 1996, Liu et al. 1996, Yang et al. 2006).

Heat stress influences physiological and biochemical mechanisms and has a significant effect on growth and energy metabolism in Apostichopus japonicus (Li et al. 2002, Yang et al. 2006, Dong et al. 2007, 2008). In re- sponse to heat stress, the activity of antioxidases (e.g. superoxide dismutase and catalase) is enhanced and the content of catechol hormones is increased (Wang et al. 2008). Changes in physiological processes under environmental stress are the result of changing gene expression (Gracey et al. 2001, De la Vega et al. 2007, Lü \& Wan 2008). A temperature increase is accompanied by increased expression of heat-shock protein 70 (Hsp70) and activation of the DNA repair system in $A$. japonicus (Dong et al. 2007, 2008), but studies have been focused on molecular chaperones and there are few reports of the expression of other genes related to heat stress. There is a need to elucidate details of the molecular regulatory mechanism in A. japonicus in response to heat stress.

Suppression subtractive hybridization (SSH) has been used in many marine animals to identify genes that are expressed differentially after exposure to sev- 
eral biotic and abiotic factors. This method has identified such genes in black tiger shrimp Penaeus monodon exposed to a range of environmental stressors (De la Vega et al. 2007). In addition, SSH has been used to study the effects of hypoxia on the mudsucker fish Gillichthys mirabilis (Gracey et al. 2001) and in blue crab Callinectes sapidus (Brouwer et al. 2004), and to analyze expression of genes in response to lipopolysaccharide challenge in mud crab Scylla paramamosain (Chen et al. 2010) and in giant freshwater prawn Macrobrachium rosenbergii (Lu et al. 2009). In the present study, SSH was used to isolate and identify the genes expressed differentially in the body wall of Apostichopus japonicus in response to an acute heat shock $\left(2 \mathrm{~h}\right.$ at $\left.28^{\circ} \mathrm{C}\right)$. The aim was to find more candidate genes involved in the response to heat stress and to gather information to aid further understanding of estivation.

\section{MATERIALS AND METHODS}

Experimental sea cucumbers. Specimens of Apostichopus japonicus (average weight: $53.8 \pm 5.7 \mathrm{~g}$ ) were collected at $19^{\circ} \mathrm{C}$ from the Yellow Sea in Jiaozhou Bay, China, on 2 June 2009 and transferred to the laboratory. The holothurians were acclimated in seawater (salinity 30) at $18^{\circ} \mathrm{C}$ in a $500 \mathrm{l}$ tank for $1 \mathrm{wk}$ with continuous aeration. Half of this water was exchanged for fresh seawater daily, and the holothurians were fed twice daily with a laboratory-made formula: $36.36 \pm$ $0.39 \%(w / w)$ water, plus $63.64 \pm 0.26 \%(w / w)$ dry matter, which included $5.04 \pm 0.19 \%(\mathrm{w} / \mathrm{w})$ crude protein, $0.26 \pm 0.05 \%(\mathrm{w} / \mathrm{w})$ fat, and $72.20 \pm 0.19 \%(\mathrm{w} / \mathrm{w})$ ash .

Heat stress test. The threshold temperature for estivation in Apostichopus japonicus is $28^{\circ} \mathrm{C}$ ( Liu et al. 1996, Yang et al. 2006), and this temperature was used to examine the relationship between heat stress and expression of the hsp70 gene in A. japonicus (Liu 2008). In the present study the same temperature was used to examine the molecular regulation mechanism underlying the heat stress response. Thirty specimens were divided randomly into 2 groups of 15 . The heattreated group was put into seawater at $28^{\circ} \mathrm{C}$ for $2 \mathrm{~h}$ and then allowed to recover for $2 \mathrm{~h}$ at $18^{\circ} \mathrm{C}$. The other group was kept at $18^{\circ} \mathrm{C}$ as the control group. After recovery, a sample of the body wall (mid-dorsal body wall near the anus) of each individual was collected, frozen with liquid nitrogen, and stored at $-80^{\circ} \mathrm{C}$.

RNA extraction. Total RNA was extracted from the frozen tissue using TRIzol ${ }^{\circledR}$ reagent (Invitrogen) following the manufacturer's instructions. Total RNA was pooled for each group (control and heat-treated), and mRNA was purified with an Oligotex mRNA kit (QIAGEN) according to the manufacturer's instructions.
SSH and construction of an SSH library. Forward and reverse $\mathrm{SSH}$ libraries were constructed for analysis of gene expression induced by heat treatment. The forward SSH library used the cDNA from the heattreated group as the tester and the cDNA from the control as the driver in order to find the up-regulated genes. The reverse SSH library was used to identify the down-regulated genes, using the cDNA from the control as a tester and the cDNA from the heat-treated group as a driver (Diatchenko et al. 1996, 1999). SSH was done with the PCR-Select ${ }^{\mathrm{TM}}$ CDNA Subtraction Kit (Clontech) according to the manufacturer's instructions. Briefly, double-stranded cDNA was generated from $2 \mu \mathrm{g}$ of extracted poly $(\mathrm{A})^{+}$RNA. The cDNA samples were precipitated in ethanol, digested with $15 \mathrm{U}$ of RsaI at $37^{\circ} \mathrm{C}$ for $2 \mathrm{~h}$, then extracted with phenol/chloroform/isoamyl alcohol (25:24:1, by vol.), followed by extraction with chloroform/isoamyl alcohol (24:1, v/v), then extracted with $4 \mathrm{M}$ ammonium acetate/95\% alcohol $(1: 7.5, \mathrm{v} / \mathrm{v})$, and twice precipitated in ethanol. Two different adaptors, Adaptor 1 and Adaptor 2R (Table 1), were ligated to the $5^{\prime}$ end of each strand of tester cDNA with $400 \mathrm{U}$ of T4 bacteriophage DNA ligase. The tester cDNA samples were each mixed with driver cDNA, denatured at $98^{\circ} \mathrm{C}$ for $90 \mathrm{~s}$, and hybridized at $68^{\circ} \mathrm{C}$ for $8 \mathrm{~h}$. After the first hybridization, the 2 mixtures were combined and hybridized again with freshly heat-denatured driver cDNAs overnight at $68^{\circ} \mathrm{C}$. The cDNAs containing both adaptors were identified by 2 rounds of PCR. The first PCR was done with Primer 1 (Table 1) against Adaptors 1 and $2 \mathrm{R}$ at $94^{\circ} \mathrm{C}$ for $25 \mathrm{~s}$, then 27 cycles of $94^{\circ} \mathrm{C}$ for $10 \mathrm{~s}, 66^{\circ} \mathrm{C}$ for $30 \mathrm{~s}$, and $72^{\circ} \mathrm{C}$ for $90 \mathrm{~s}$. The amplified products were used as a template in the second PCR with Nested primers 1 and $2 \mathrm{R}$ (Table 1 ). The reaction was 12 cycles at $94^{\circ} \mathrm{C}$ for $10 \mathrm{~s}, 68^{\circ} \mathrm{C}$ for $30 \mathrm{~s}, 72^{\circ} \mathrm{C}$ for $90 \mathrm{~s}$, and a final extension at $72^{\circ} \mathrm{C}$ for $5 \mathrm{~min}$.

The PCR products were purified after precipitation in ethanol as follows: $50 \mathrm{ng}$ of insert was ligated to pGEM ${ }^{\circledR}-\mathrm{T}$ easy vector (Promega) and used to transform DH5 $\alpha$-competent cells according to the manufacturer's instructions. Transformed cells were grown overnight at $37^{\circ} \mathrm{C}$ on an Luria-Bertani (LB) agar plate containing $100 \mu \mathrm{g} \mathrm{ml}^{-1}$ ampicillin.

Identification of positive clones. White colonies were picked at random from each SSH library and inserted into $1.5 \mathrm{ml}$ of LB medium containing $100 \mu \mathrm{g}$ $\mathrm{ml}^{-1}$ ampicillin and incubated overnight at $37^{\circ} \mathrm{C}$. The PCR reaction was done with $0.2 \mu$ of culture with Nested primers 1 and 2R (Table 1). The PCR reaction profile was: $10 \mathrm{~min}$ at $94^{\circ} \mathrm{C}$, then 25 cycles of $94^{\circ} \mathrm{C}$ for $10 \mathrm{~s}, 68^{\circ} \mathrm{C}$ for $30 \mathrm{~s}, 72^{\circ} \mathrm{C}$ for $90 \mathrm{~s}$, and a final extension at $72^{\circ} \mathrm{C}$ for $5 \mathrm{~min}$. The inserted fragment size of the chosen clones was identified by $1.5 \%(\mathrm{w} / \mathrm{v})$ agarose gel electrophoresis and the selected clones were iden- 
Table 1. Oligonucleotide primer and adaptor sequences. F: forward; R: reverse

\begin{tabular}{|c|c|c|c|}
\hline Primer & Target gene & Sequence & Product size (bp) \\
\hline $\begin{array}{l}\text { Hsp20.8 (F) } \\
\text { Hsp20.8 (R) }\end{array}$ & HSP20.8 & $\begin{array}{l}\text { 5'-AGG GAA GAA GGA GGA GGT-3' } \\
\text { 5'-TGC ATA AAC AGC GTC ATA G-3' }\end{array}$ & 191 \\
\hline $\begin{array}{l}\text { Hsp90 (F) } \\
\text { Hsp90 (R) }\end{array}$ & HSP90 & $\begin{array}{l}\text { 5'-CCA TGT CTT CTT TAA GGG TCA-3' } \\
\text { 5'-CCA GTT TGG TGT TGG CT-3' }\end{array}$ & 170 \\
\hline $\begin{array}{l}\text { Hsp70 (F) } \\
\text { Hsp70 (R) }\end{array}$ & HSP70 & $\begin{array}{l}\text { 5'-CAC CAA GGA CGC AGG AGT-3' } \\
\text { 5'-CAC CGT TAT CAA TGG TCA GG-3' }\end{array}$ & 173 \\
\hline $\begin{array}{l}\text { Ferritin (F) } \\
\text { Ferritin (R) }\end{array}$ & Ferritin & $\begin{array}{l}\text { 5'-CGC TTC AGA TTG GTG ATG TGG T-3' } \\
\text { 5'-GAA GAA CGT GAA CAT GCC GAG A-3' }\end{array}$ & 290 \\
\hline $\begin{array}{l}\text { Zinc finger }(F) \\
\text { Zinc finger }(\mathrm{R})\end{array}$ & Zinc finger protein & $\begin{array}{l}\text { 5'-GTC GCT GAA CCA AGA TAG CC-3' } \\
\text { 5'-CCA AAC CGG TAG CAC CTA AG-3' }\end{array}$ & 165 \\
\hline $\begin{array}{l}\operatorname{COX}(\mathrm{F}) \\
\operatorname{COX}(\mathrm{R})\end{array}$ & Cytochrome $c$ oxidase & $\begin{array}{l}\text { 5'- AGC AGG AAT GGT TGG AAC AG -3' } \\
5^{\prime}-\text { GCC ATG TCT GGA GCA CCT AT -3' }\end{array}$ & 204 \\
\hline $\begin{array}{l}\mathrm{CoA}(\mathrm{F}) \\
\mathrm{CoA}(\mathrm{R})\end{array}$ & Succinyl-CoA synthetase & $\begin{array}{l}\text { 5'-AAG CCT GGT CAG TGC AAG AT-3' } \\
\text { 5'-TGT CCA GGC AGT CAA CAA AG-3' }\end{array}$ & 196 \\
\hline $\begin{array}{l}\text { Histone }(F) \\
\text { Histone }(\mathrm{R})\end{array}$ & Histone & $\begin{array}{l}\text { 5'-CTG CCT GTT CAA TCA AAG CA-3' } \\
\text { 5'-CAA GCG TGT AAC CAT CAT GC-3' }\end{array}$ & 234 \\
\hline $\begin{array}{l}\text { Actin }(F) \\
\text { Actin (R) }\end{array}$ & $\beta$-actin & $\begin{array}{l}\text { 5'-CAT TCA ACC CTA AAG CCA ACA-3' } \\
\text { 5'-TGG CGT GAG GAA GAG CAT-3' }\end{array}$ & 198 \\
\hline $\begin{array}{l}\text { NADH (F) } \\
\text { NADH (R) }\end{array}$ & NADH-ubiquinone oxidoreductase & $\begin{array}{l}\text { 5'-GTC CTA CGA CCC AAT CTG GA-3' } \\
\text { 5'-ATG AGC CTT GGT TAC GTT GG-3' }\end{array}$ & 196 \\
\hline Adaptor 1 & & $\begin{array}{l}\text { 5'-CTA ATA CGA CTC ACT ATA GGG CTC } \\
\text { GAG CGG CCG CCC GGG CAG GT-3' }\end{array}$ & \\
\hline Adaptor 2R & & $\begin{array}{l}\text { 5'-CTA ATA CGA CTC ACT ATA GGG CAG } \\
\text { CGT GGT CGC GGC CGA GGT-3' }\end{array}$ & \\
\hline Primer 1 & & 5'-CTA ATA CGA CTC ACT ATA GGG C-3' & \\
\hline Nested primer 1 & & 5'-TCG AGC GGC CGC CCG GGC AGG T-3' & \\
\hline Nested primer $2 \mathrm{R}$ & & 5'-AGC GTG GTC GCG GCC GAG GT-3' & \\
\hline
\end{tabular}

tified by dot hybridization; the forward probe was the 2-round PCR products of the forward library labeled with $\left[\alpha-{ }^{32} \mathrm{P}\right] \mathrm{dATP}$, and the reverse probe was the 2round PCR products of the reverse library. Preparation of the probe was done with the Amersham Megaprime DNA Labeling System (GE Healthcare) according to the manufacturer's instructions: the products of 2round PCRs in both libraries were each allowed to react separately with primer at $95^{\circ} \mathrm{C}$ for $10 \mathrm{~min}$, then $\left[\alpha-{ }^{32} \mathrm{P}\right] \mathrm{dATP}$ was added and the mixture was incubated at $37^{\circ} \mathrm{C}$ for $1 \mathrm{~h}$. The reaction was terminated with $2 \mu \mathrm{l}$ of $500 \mathrm{mM}$ EDTA and the products were stored at $-20^{\circ} \mathrm{C}$. The denatured PCR product $(1 \mu \mathrm{l})$ was spotted onto nylon membrane and hybridized at $68^{\circ} \mathrm{C}$ for $3 \mathrm{~h}$. A $\left[\alpha-{ }^{32} \mathrm{P}\right] \mathrm{dATP}-\mathrm{labeled}$ probe was added for hybridization at $68^{\circ} \mathrm{C}$ overnight. Each clone was done in triplicate. An average ratio (intensity of signal with forward probe divided by intensity of signal with reverse probe) of at least 2 (in the forward library) or at most 0.05 (in the reverse library) was considered positive and was selected for further analysis.

Clone sequence and analysis. Positive clones were sequenced using ABI 3730 automated sequencers (Applied Biosystems) at Shanghai United Gene Group. The sequences obtained were analyzed by DNAstar for alignment. Nucleotide homology comparison was done with the basic local alignment search tool (BLAST), using BLASTn, BLASTx, and BLASTp (www. ncbi.nlm.nih.gov/BLAST). For each comparison, a BLAST $E$-value $<10^{-5}$ was regarded as a positive result. Gene ontology (GO) annotation was analyzed in the GO database (http://amigo.geneontology.org/cgibin/amigo/go.cgi) using AmiGO.

Real-time PCR analysis. Reference gene selection: Two reference genes (those coding for NADH-ubiquinone oxidoreductase and $\beta$-actin) were selected for analysis. The specific primers for these 2 genes were designed using sequences in GenBank (accession no. EU668024) for $\beta$-actin, and the Apostichopus japonicus expressed sequence tag (EST) database, which was constructed in our laboratory using the 454 sequencing system, for NADH-ubiquinone oxidoreductase (Table 1). For comparison of control and heattreated individuals, the expression of the gene coding for $\beta$-actin in A. japonicus was the same irrespective of conditions and therefore was selected as the reference gene for this species.

Confirmation of subtraction efficiency: To evaluate subtraction efficiency, real-time PCR was used to analyze the depletion of transcript abundance of the gene coding for $\beta$-actin in the subtracted tester cDNA compared to the unsubtracted cDNA. The primer informa- 
tion is given in Table 1 and each reaction was run in triplicate. The reaction profile was denaturation at $95^{\circ} \mathrm{C}$ for $10 \mathrm{~s}$, then 40 cycles of $95^{\circ} \mathrm{C}$ for $5 \mathrm{~s}, 59^{\circ} \mathrm{C}$ for $20 \mathrm{~s}$, $72^{\circ} \mathrm{C}$ for $30 \mathrm{~s}$, followed by a melt curve step in Mastercycler ${ }^{\circledR}$ ep realplex (Eppendorf). The data were analyzed with realplex software version 2.2 (Eppendorf).

Confirmation of differential expression: Eight different clones were selected and the different levels of gene expression in the sea cucumber body wall in response to heat stress were analyzed by real-time quantitative PCR (qPCR). RNA extraction and cDNA synthesis were done as described in 'Materials and methods - RNA extraction'. Briefly, $2 \mu \mathrm{g}$ of total RNA was reverse-transcribed using $200 \mathrm{U}$ of M-MLV reverse transcriptase (Promega), $40 \mathrm{U}$ of cloned ribonuclease inhibitor (Takara), and a $5 \mu \mathrm{M}$ dNTP mixture in a reaction volume of $25 \mu \mathrm{l}$. cDNAs were diluted in nuclease-free water and stored at $-20^{\circ} \mathrm{C}$.

Real-time qPCR was done in a $25 \mu$ reaction mixture containing $2 \mu \mathrm{l}$ of cDNA, $0.2 \mu \mathrm{mol}$ of each gene-specific primer (Table 1), and $12.5 \mu$ l of SYBR Green PCR Master Mix (Takara). Each reaction was run in triplicate. The reaction profile was $95^{\circ} \mathrm{C}$ for $10 \mathrm{~s}$, followed by 40 cycles of $95^{\circ} \mathrm{C}$ for $5 \mathrm{~s}, 59^{\circ} \mathrm{C}$ for $20 \mathrm{~s}$, and $72^{\circ} \mathrm{C}$ for $30 \mathrm{~s}$. After PCR, melting curve analysis was used to demonstrate the specificity of the PCR products. All products generated a single, discrete peak in the melting curve analysis. The average $C_{\mathrm{t}}$ value of each triplicate reaction was calculated using realplex software version 2.2 with the gene coding for $\beta$-actin as the reference gene. Statistical analysis was done by ANOVA using SPSS software (version 11.5), and the level of statistical significance was set at $\mathrm{p}<0.05$.

\section{RESULTS}

\section{Sequencing and analysis of clones in the SSH library}

Forward and reverse SSH libraries were constructed to identify Apostichopus japonicus genes in the body wall that demonstrated a change of expression in response to heat stress. Due to the lack of molecular information about this holothurian, we selected 768 cDNA clones at random from both libraries and amplified them by PCR; an average insert size of $478 \mathrm{bp}$ (range: 200 to $1000 \mathrm{bp}$ ) was observed. Using dot hybridization, 737 clones with a ratio of at least 2 (in the up-regulated library) or at most 0.05 (in the downregulated library) were selected, it was found that in the forward library $63.8 \%(231 / 362)$ clones represented the gene encoding HSP70. PCR products were assembled and edited. Finally, 165 ESTs were obtained: 117 in the down-regulated library and 48 in the up-regulated library.
Comparison of the 165 distinct EST sequences to those in GenBank revealed that 65 had a high level of similarity to genes with known function (BLAST $E$ value $<10^{-5}$ ) and 100 sequences had no significant similarity to any gene (BLAST E-value $>10^{-5}$ ). After assembly of the 165 sequences, 46 unique genes were identified: 14 were found only in the up-regulated library, 29 only in the down-regulated library, and 3 in both libraries (Table 2). The functions of ESTs with significant similarity to sequences in the databases were predicted by AmiGO. All genes were clustered by function (Fig. 1), and in the up-regulated library, genes related to a response to stimulus showed changed expression, but expression of some genes participating in cell component or biological processes (growth, organelle part, etc.) was not observed.

\section{Subtraction efficiency}

The subtraction efficiency was determined by realtime qPCR amplification of a housekeeping gene (that coding for $\beta$-actin) in subtracted and unsubtracted cDNAs. The amount of $\beta$-actin template in unsubtracted cDNAs was $10^{3}$ - to $10^{4}$-fold greater than the amount in subtracted cDNAs (Fig. 2). Expression of the housekeeping gene was clearly decreased after $\mathrm{SSH}$.

\section{Levels of gene expression}

Using real-time qPCR, the expression of 8 genes with different functions in Apostichopus japonicus was determined (Fig. 3). All of these genes showed a changed level of expression in response to heat stress. Expression of the mRNA of the heat-shock protein family was significantly different after the heat shock, and expression of the genes encoding the zinc finger protein and ferritin was also increased significantly after the heat shock. The expression of the genes coding for histone, succinyl-CoA synthetase, and cytochrome $c$ oxidase (COX) was decreased in response to heat stress. Following the heat shock, the level of expression changed significantly $(p<0.05)$ for 7 of the 8 genes but not for the gene encoding histone.

\section{DISCUSSION}

\section{Change of gene expression under heat stress in Apostichopus japonicus}

Water temperature has an important influence on the activity and survival of marine animals (Fisher 1988, Wang \& Li 2002, Monari et al. 2007, Dong et al. 
Table 2. Different expression clones in Apostichopus japonicus heat-shock suppression subtractive hybridization libraries with BLASTp (BLAST $E$-value $<10^{-5}$ ). Down: reverse library; up: forward library

\begin{tabular}{|c|c|c|c|c|c|c|}
\hline Clone ID & Redundancy & Gene coding for & Species with homology to & GenBank accession no. & Library & $E$-value \\
\hline HO054974 & 7 & Heat shock protein 70 & Apostichopus japonicus & ACJ54702.1 & $\mathrm{Up}$ & $1 \times 10^{-123}$ \\
\hline HO054975 & 1 & Ferritin & Apostichopus japonicus & AAY89589.1 & $\mathrm{Up}$ & $1 \times 10^{-63}$ \\
\hline HO054976 & 3 & Heat shock protein 90 -alpha & Salmo salar & ACN10985.1 & $\mathrm{Up}$ & $3 \times 10^{-74}$ \\
\hline HO054977 & 3 & Heat shock protein 20.8 & Liriomyza sativae & ABE57141.1 & $\mathrm{Up}$ & $3 \times 10^{-10}$ \\
\hline HO054978 & 2 & Zinc finger protein & Strongylocentrotus purpuratus & XP_785663.2 & $\mathrm{Up}$ & $8 \times 10^{-69}$ \\
\hline HO054981 & 1 & Ribosomal proteinL32 & Strongylocentrotus purpuratus & XP_782126.1 & $\mathrm{Up}$ & $2 \times 10^{-43}$ \\
\hline HO054982 & 1 & Dna J (hsp40) homolog & Danio rerio & NP_956067.1 & $\mathrm{Up}$ & $1 \times 10^{-41}$ \\
\hline HO054983 & 1 & Putative 60 S ribosomal protein & Novocrania anomala & ACD65123.1 & $\mathrm{Up}$ & $2 \times 10^{-34}$ \\
\hline HO054984 & 1 & Predicted protein & Nematostella vectensis & XP_001625396.1 & $\mathrm{Up}$ & $1 \times 10^{-30}$ \\
\hline HO054985 & 1 & Ribosomal protein rpl7a & Arenicola marina & ABW23163.1 & $\mathrm{Up}$ & $1 \times 10^{-18}$ \\
\hline HO054986 & 1 & $\begin{array}{l}\text { Similar to Protein lethal (2) } \\
\text { essential for life }\end{array}$ & Apis mellifera & XP_001120194.1 & Up & $2 \times 10^{-14}$ \\
\hline HO054987 & 1 & Alpha B crystallin & Homo sapiens & ACP18852.1 & $\mathrm{Up}$ & $5 \times 10^{-10}$ \\
\hline HO054988 & 1 & Pherophorin-dz1 protein & Volvox carteri f. nagariensis & CAD22154.1 & Up & $2 \times 10^{-9}$ \\
\hline HO054989 & 1 & Unnamed protein product & Tetraodon nigroviridis & CAF90222.1 & $\mathrm{Up}$ & $2 \times 10^{-13}$ \\
\hline HO054979 & 2 & Myosin heavy chain & Strongylocentrotus purpuratus & XP_785810.2 & Both & $1 \times 10^{-80}$ \\
\hline HO054980 & 3 & Major yolk protein 2 & Apostichopus japonicus & BAH79577.1 & Both & $4 \times 10^{-34}$ \\
\hline HO055005 & 3 & Alpha-5 collagen & Strongylocentrotus purpuratus & XP_795694.2 & Both & $2 \times 10^{-15}$ \\
\hline HO056151 & 1 & Major yolk protein 1 & Apostichopus japonicus & BAH79576.1 & Down & $1 \times 10^{-117}$ \\
\hline HO054990 & 1 & $\begin{array}{l}\text { Succinyl-CoA synthetase } \\
\text { alpha subunit }\end{array}$ & Strongylocentrotus purpuratus & XP_786544.2 & Down & $3 \times 10^{-83}$ \\
\hline HO054991 & 3 & Cytochrome $c$ oxidase, subunit Va & Strongylocentrotus purpuratus & XP_784558.1 & Down & $2 \times 10^{-58}$ \\
\hline HO054992 & 1 & $\begin{array}{l}\text { Scavenger receptor cysteine-rich } \\
\text { protein type } 12\end{array}$ & Strongylocentrotus purpuratus & NP_999762.1 & Down & $4 \times 10^{-79}$ \\
\hline HO054993 & 1 & Elongation factor & Caenorhabditis elegans & AAD03339.1 & Down & $3 \times 10^{-57}$ \\
\hline HO054994 & 2 & NADH dehydrogenase subunit 1 & Apostichopus japonicus & ACM66296.1 & Down & $1 \times 10^{-55}$ \\
\hline HO054995 & 1 & Ribosomal protein rps12 & Eurythoe complanata & ABW23206.1 & Down & $3 \times 10^{-55}$ \\
\hline HO054996 & 1 & 60S ribosomal protein L9 & Ictalurus punctatus & Q90YW0.1 & Down & $4 \times 10^{-46}$ \\
\hline HO054997 & 1 & Annexin & Strongylocentrotus purpuratus & XP_795341.2 & Down & $3 \times 10^{-38}$ \\
\hline HO054998 & 1 & Ribosomal protein L30 & Strongylocentrotus purpuratus & XP_783150.1 & Down & $4 \times 10^{-38}$ \\
\hline HO054999 & 1 & Complement component C3 & Strongylocentrotus purpuratus & XP_001185680.1 & Down & $3 \times 10^{-37}$ \\
\hline HO055000 & 1 & Predicted protein & Nematostella vectensis & XP_001625568.1 & Down & $2 \times 10^{-36}$ \\
\hline HO055001 & 1 & H3.3 histone & Strongylocentrotus purpuratus & XP_791401.1 & Down & $5 \times 10^{-35}$ \\
\hline HO055002 & 1 & Ribosomal protein L44 & Strongylocentrotus purpuratus & XP_797556.2 & Down & $1 \times 10^{-34}$ \\
\hline HO055003 & 1 & $\begin{array}{l}\text { Hypothetical protein } \\
\text { BRAFLDRAFT_88602 }\end{array}$ & Branchiostoma floridae & XP_002604312.1 & Down & $2 \times 10^{-31}$ \\
\hline HO055004 & 1 & Neurotrypsin & Danio rerio & XP_690649.2 & Down & $3 \times 10^{-30}$ \\
\hline HO055006 & 1 & $\begin{array}{l}\text { Hypothetical protein } \\
\text { BRAFLDRAFT_74514 }\end{array}$ & Branchiostoma floridae & XP_002598809.1 & Down & $3 \times 10^{-21}$ \\
\hline HO055007 & 1 & Septin $7 \mathrm{~b}$ isoform 2 & Danio rerio & NP_001119922.1 & Down & $8 \times 10^{-21}$ \\
\hline HO055008 & 1 & Complement C4 & Oncorhynchus mykiss & NP_001117857.1 & Down & $4 \times 10^{-7}$ \\
\hline HO055009 & 1 & C14orf147 homolog & Oncorhynchus mykiss & ACO08325.1 & Down & $1 \times 10^{-6}$ \\
\hline HO055010 & 1 & MEGF10 protein & Gallus gallus & XP_424719.2 & Down & $1 \times 10^{-21}$ \\
\hline HO055011 & 1 & 60S ribosomal protein L35 & Lycosa singoriensis & ABX75380.1 & Down & $1 \times 10^{-16}$ \\
\hline HO055012 & 1 & $\begin{array}{l}\text { AMPA receptor subunit } \\
\text { GluR3B, partial }\end{array}$ & Strongylocentrotus purpuratus & XP_001188377.1 & Down & $4 \times 10^{-12}$ \\
\hline HO055013 & 1 & GD11645 & Drosophila simulans & XP_002082584.1 & Down & $1 \times 10^{-6}$ \\
\hline HO055014 & 1 & Brain RPTPmam4 iso-form II & Strongylocentrotus purpuratus & XP_783327.1 & Down & $3 \times 10^{-6}$ \\
\hline HO055015 & 1 & MGC97760 protein & Xenopus (Silurana) tropicalis & NP_001015831.1 & Down & $1 \times 10^{-5}$ \\
\hline HO055016 & 1 & Predicted protein & Trichoplax adhaerens & XP_002109456.1 & Down & $3 \times 10^{-5}$ \\
\hline HO055017 & 1 & $\begin{array}{l}\text { Hypothetical protein } \\
\text { PANDA_006529 }\end{array}$ & Ailuropoda melanoleuca & EFB29313.1 & Down & $7 \times 10^{-25}$ \\
\hline HO055018 & 1 & Ribosomal protein L23a & Strongylocentrotus purpuratus & XP_001201900.1 & Down & $7 \times 10^{-9}$ \\
\hline
\end{tabular}




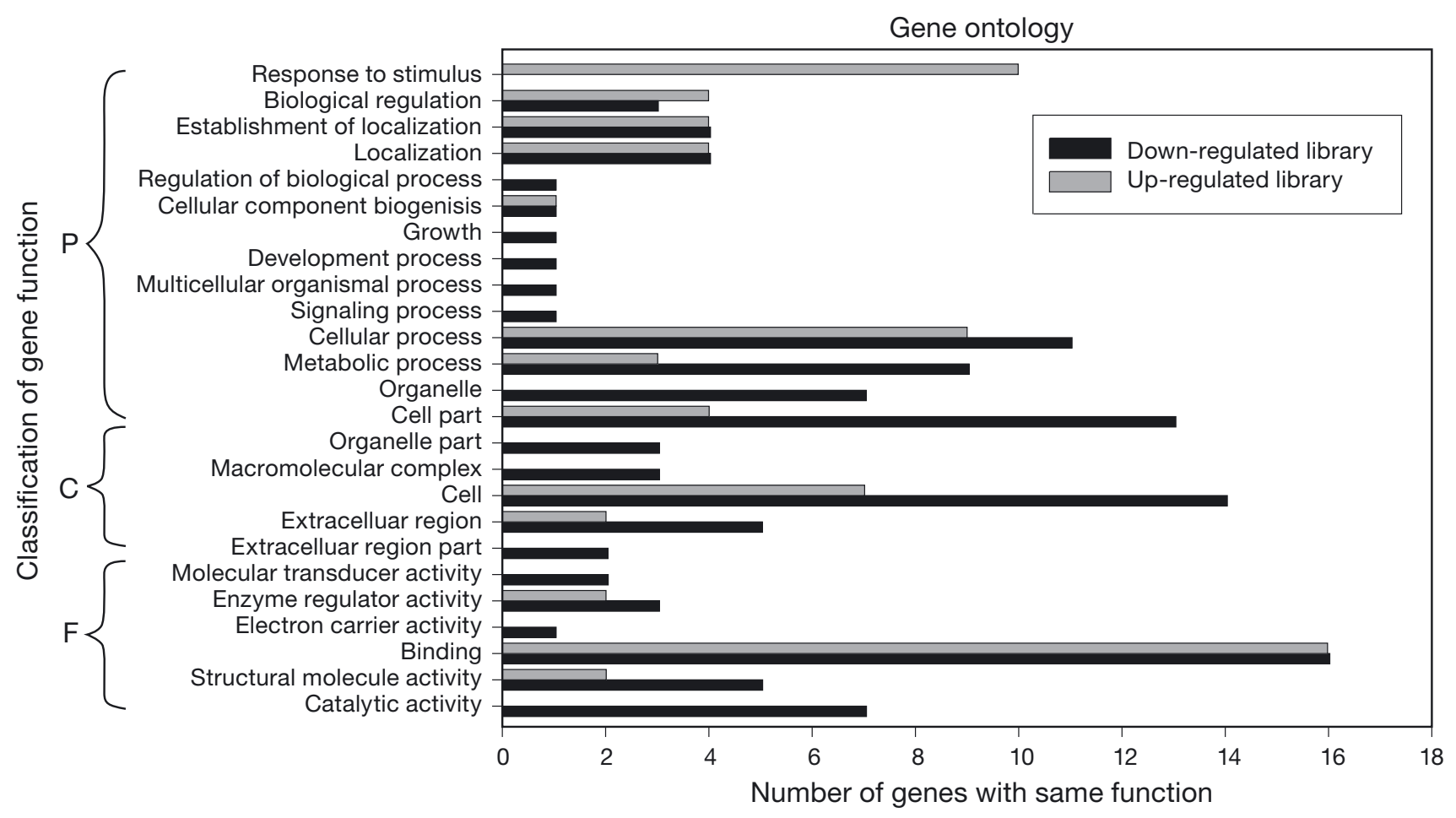

Fig. 1. Distribution of genes screened from suppression subtractive hybridization library from heat-shocked Apostichopus japonicus by functional class. P: biological process; C: cell component; F: molecular function

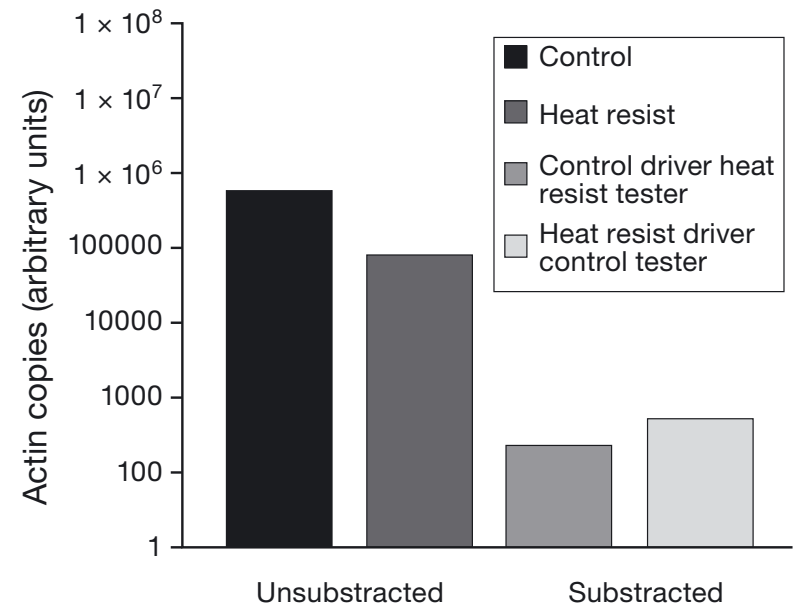

Fig. 2. Real-time quantitative PCR analysis of transcript abundance of the gene coding for $\beta$-actin during suppression subtractive hybridization (SSH). Left 2 vertical bars represent concentration of $\beta$-actin gene in unsubtracted control nested PCR reactions; right 2 bars represent concentration of $\beta$-actin gene in nested PCR reactions following $\mathrm{SSH}$

2008). In the present study, forward and reverse suppression subtraction libraries were constructed from the Apostichopus japonicus body wall in order to analyze the changed levels of gene expression in response to heat stress. The genes potentially involved were sequenced and analyzed. Because of the lack of related information, most of the ESTs were unknown on the

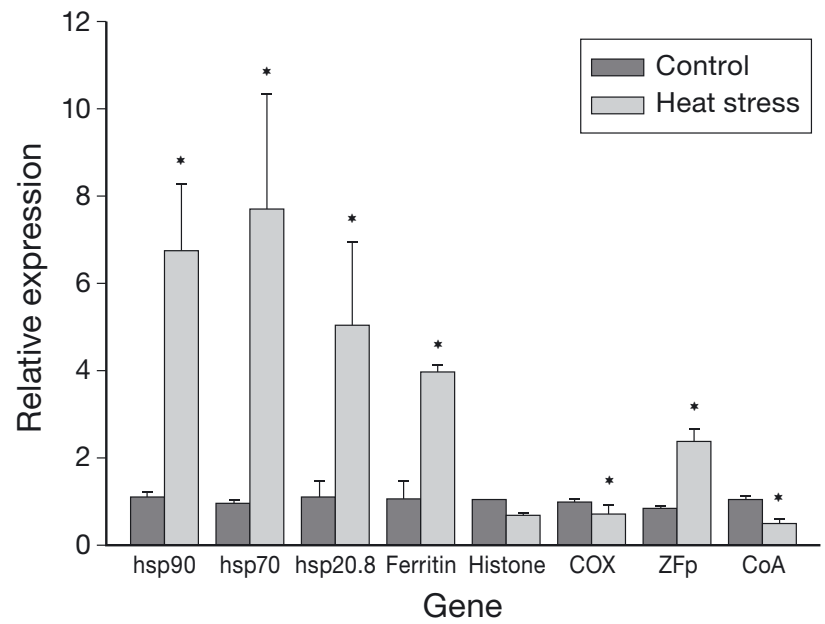

Fig. 3. Expression analysis of different genes in heat-shocked Apostichopus japonicus with real-time quantitative PCR. * Significant difference between treated and control groups $(\mathrm{p}<0.05)$. COX: cytochrome $c$ oxidase; CoA: succinyl-CoA synthetase; ZFp: zinc finger protein. All data are mean \pm SD. $\mathrm{n}=15$ sea cucumbers treatment ${ }^{-1}$

basis of the BLASTn and BLASTp results. Some of the known ESTs belonged to heat-shock proteins and genes involved in immunity, and binding molecules such as the genes coding for ferritin and zinc finger protein were identified in the forward library. Genes functional in cell component and molecular function were verified in the reverse library, but were not 
expressed in the forward library. These results suggest that these libraries reveal a response to heat stress in A. japonicus.

Identification of the same contig in both libraries (e.g. genes coding for collagen and myosin) revealed false-positive clones and is likely to be the result of an incomplete subtraction of some genes. But differential expression of 8 randomly selected genes suggests that the rate of false-positive clones was very low.

\section{Chaperone}

Heat-shock proteins are chaperones that allow biological processes to work well in a stressful environment. Hsp70, which has been studied widely owing to its sensitivity to stress (Boone \& Vijayan 2002, Hamer et al. 2004, Lund et al. 2006), is an important non-specific protein that protects enzymes from heat damage and supervises the accuracy of protein folding and the allocation of new polypeptides, and it speeds the recovery of protein synthesis. Hsp70 repairs protein misfolding and accelerates the degradation of protein that cannot be repaired. Therefore, increased expression of Hsp70 increases the tolerance of organisms to stress and improves the rate of cell survival (Nakano \& Iwama 2002). In the present study, $63.8 \%$ (231/362) of the clones in the forward library represented the gene encoding Hsp70. The results of real-time qPCR confirmed that the expression of $h s p 70$ gene transcripts was up-regulated significantly in response to heat stress in Apostichopus japonicus. This indicates that the acute heat shock severely damaged cell function but the negative effect was eliminated because the organism expressed large amounts of hsp70, which helped to maintain physiological balance.

Transcripts for Hsp90 and the genes coding for small heat-shock proteins (sHSPs) were identified in the forward library, and this had not been reported previously for this holothurian. It has been reported that sHSP is an energy-dependent molecular chaperone in other species, where it has an important role in protecting the cell from stress-induced damage by preventing irreversible aggregation or by promoting correct substrate folding (Sun et al. 2002, Sun \& MacRae 2005). HSP90 contributes to the correct folding that maintains the structural integrity of proteins and regulates cytosolic proteins and works with other client proteins to take advantage of its function (Picard 2002, Queitsch et al. 2002, Chen et al. 2006). In the present study, different levels of expression of genes coding for Hsp90, Hsp70, and sHSP transcripts in response to heat stress were observed simultaneously, which indicates that the contributions of these genes were not identical. We suggest that they interact and enhance the heat tolerance in Apostichopus japonicus, limiting heat stress-induced damage to the organism and maintaining physiological balance. The relationship among these proteins was not revealed in the present study and it should be the subject of further research.

\section{Genes related to immunity}

Zinc finger protein is a DNA-binding protein that is part of the stress-response element (STRE) containing promoters. The amount of zinc finger protein in cells appears to be small under favorable conditions; however, transcription is increased and this protein is among the STREs when unfavorable conditions are encountered. Therefore, STRE-dependent transcriptional induction normally occurs rapidly (Kim et al. 2005, Jang et al. 2007). In the present study, expression of the gene coding for the zinc finger protein increased 2 -fold after heat stress and this increase, together with the enhancement of some regulated factors, strengthened the defense of the organism and reduced the damage to cell function.

Ferritin is an iron-chelator protein involved in cellular protection from oxidative stress and integrated stress responses, also known as the acute phase response. Expression of gene coding for ferritin in the edible periwinkle Littorina littorea is increased in response to anoxic stress (Beck et al. 2002, Larade \& Storey 2004). The presence of a ferritin-like clone in the forward library suggests an increase in mRNA expression in response to heat stress. This result is in accord with the increased activity of other immune enzymes (superoxide dismutase and catalase) under heat stress in Apostichopus japonicus (Dong et al. 2007). This suggests that, in order to maintain cell structure and function under heat stress, transcription of genes related to immunity is enhanced, which removes the oxidative products.

In the present study, some EST sequences categorized as recognition receptors, complement components, and growth factors were found in the reverse library. These genes are involved in the innate defense of the brown rock sea cucumber Holothuria glaberrima (RamírezGómez et al. 2008) and in the purple sea urchin Strongylocentrotus purpuratus (Gross et al.1999, Rast et al. 2000, Hibino et al. 2006). We concluded that heat stress can influence the innate defense of Apostichopus japonicus.

\section{Genes related to energy production and metabolism}

After heat stress, the concentration of oxygen radicals can increase and damage the structure and function of the cell membrane; as a result, the rate of elec- 
tron transport decreases, which frees more energy for defense against an environmental stress. COX plays a key role in the electron transport chain, where it catalyses the reduction of molecular oxygen to water concomitant with the oxidation of reduced cytochrome $C_{\text {, }}$ and couples this redox reaction with the electrogenic transfer of protons across the inner mitochondrial membrane (Parker et al. 1994, Shigenaga et al. 1994). The sea cucumber body wall has a respiratory function and requires oxygen. In the present study, there was a decrease in the expression of genes coding for COX, which can be related to an increase in reactive oxygen species and ATP synthesis after heat stress, which is necessary for the survival of this holothurian.

Both the electron transport chain and the tricarboxylic acid (TCA) cycle produce energy for metabolic processes. Some studies found that the rate of the TCA cycle was decreased in response to environmental stress; the activity of enzymes in the TCA cycle decreased significantly in snail, frog, and lungfish during seasonal hibernation (St-Pierre \& Boutilier 2001, Bishop et al. 2002, Frick et al. 2008). The activity of these enzymes in Apostichopus japonicus has not been analyzed. In the present study, however, several genes involved in the TCA cycle were found in the reverse SSH library, which indicates that expression of these genes was depressed. An analysis of enzyme activity is needed to determine whether heat stress induces depression of the metabolic rate and suppression of ATP utilization in cellular processes.

\section{Sequences of unknown function}

Due to the paucity of information available for Apostichopus japonicus, there were 100 EST sequences in our 2 libraries that had no significant similarity to any genes (BLAST E-value $>10^{-5}$ ). Some sequences were either too short or were part of an mRNA untranslated region (UTR), but some sequences were long enough to contain a significant open reading frame (OrtizPineda et al. 2009). The relatively long sequences with significant differential expression were probably associated with the regulatory and metabolic responses to heat stress. Further analysis using RNA interference and other techniques is needed to verify the function of these sequences.

Changing water temperature is one of the important environmental factors affecting biological processes in Apostichopus japonicus. The present study confirms that heat stress significantly affects the molecular mechanisms in the A. japonicus body wall with increased expression of most chaperones and immune genes and decreased expression of genes related to metabolism. The results are consistent with the phe- nomenon of estivation, when biological metabolic processes are slowed and the state of the immune system is different from that of 'normal' A. japonicus. The present study provides information for further understanding of estivation in A. japonicus, and the relationship between heat stress and A. japonicus health, and will aid in the development of sea-cucumber aquaculture.

Acknowledgments. This work was supported by the agricultural seed project of Shan Dong province and the Government of China National High Technology Research and Development Program 863 (2006AA10A411).

\section{LITERATURE CITED}

Beck G, Ellis TW, Habicht GS, Schluter SF, Marchalonis JJ (2002) Evolution of the acute phase response: iron release by echinoderm (Asterias forbesi) coelomocytes, and cloning of an echinoderm ferritin molecule. Dev Comp Immunol 26:11-26

Bishop T, St-Pierre J, Brand MD (2002) Primary causes of decreased mitochondrial oxygen consumption during metabolic depression in snail cells. Am J Physiol Regul Integr Comp Physiol 282:372-382

Boone AN, Vijayan MM (2002) Glucocorticoid-mediated attenuation of the hsp70 response in trout hepatocytes involves the proteasome. Am J Physiol Regul Integr Comp Physiol 283:680-687

> Brouwer M, Larkin P, Brown-Peterson N, King C, Manning S, Denslow N (2004) Effects of hypoxia on gene and protein expression in the blue crab, Callinectes sapidus. Mar Environ Res 58:787-792

> Chen B, Zhong D, Monteiro A (2006) Comparative genomics and evolution of the HSP90 family of genes across all kingdoms of organisms. BMC Genomics 7:156-174

> Chen FY, Liu HP, Bo J, Ren HL, Wang KJ (2010) Identification of genes differentially expressed in hemocytes of Scylla paramamosain in response to lipopolysaccharide. Fish Shellfish Immunol 28:167-177

Choe S (1963) Study of sea cucumber: morphology, ecology and propagation of sea cucumber. Kaibundou Publishing House, Tokyo

> De la Vega E, Degnan BM, Hall MR, Wilson KJ (2007) Differential expression of immune-related genes and transposable elements in black tiger shrimp (Penaeus monodon) exposed to a range of environmental stressors. Fish Shellfish Immunol 23:1072-1088

Diatchenko L, Lau YF, Campbell AP, Chenchik A, Moqadam F, Huang B (1996) Suppression subtractive hybridization: a method for generating differentially regulated or tissuespecific cDNA probes and libraries. Proc Natl Acad Sci USA 93:6025-6030

Diatchenko L, Lukyanov S, Lau YF, Siebert PD (1999) Suppression subtractive hybridization: a versatile method for identifying differentially expressed genes. Methods Enzymol 303:349-380

Dong YW, Ji TT, Dong SL (2007) Stress responses to rapid temperature changes of the juvenile sea cucumber (Apostichopus japonicus Selenka). J Ocean Univ China 6: 275-280

$>$ Dong YW, Dong SL, Ji TT (2008) Effects of different thermal regimes on growth and physiological performance of the sea cucumber Apostichopus japonicus Selenka. Aquaculture 275:329-334 
Fisher WS (1988) Environmental influence on host response. Am Fish Soc Spec Publ 18:225-237

Frick NT, Bystriansky JS, Ip YK, Chew SF, Ballantyne JS (2008) Lipid, ketone body and oxidative metabolism in the African lungfish Protopterus dolloi following 60 days of fasting and aestivation. Comp Biochem Physiol A 151:93-101

$>$ Gracey AY, Troll JV, Somero GN (2001) Hypoxia-induced gene expression profiling in the euryoxic fish Gillichthys mirabilis. Proc Natl Acad Sci USA 98:1993-1998

Gross PS, Al-Sharif WZ, Clow LA, Smith LC (1999) Echinoderm immunity and the evolution of the complement system. Dev Comp Immunol 23:429-442

Hamer B, Hamer DP, Müller WEG, Batel R (2004) Stress-70 proteins in marine mussel Mytilus galloprovincialis as biomarkers of environmental pollution: a field study. Environ Int 30:873-882

Hibino T, Loza-Coll M, Messier C, Majeske AJ, Cohen AH, Terwilliger DP (2006) The immune gene repertoire encoded in the purple sea urchin genome. Dev Biol 300:349-365

Jang JY, Lee SH, Rhee JY, Chung GC, Ahn SJ, Kang H (2007) Transgenic Arabidopsis and tobacco plants overexpressing an aquaporin respond differently to various abiotic stresses. Plant Mol Biol 64:621-632

Kim YO, Kim JS, Kang H (2005) Cold-inducible zinc fingercontaining glycine-rich RNA-binding protein contributes to the enhancement of freezing tolerance in Arabidopsis thaliana. Plant J 42:890-900

Larade K, Storey KB (2004) Accumulation and translation of ferritin heavy chain transcripts following anoxia exposure in a marine invertebrate. J Exp Biol 207:1353-1360

Li FX, Liu YH, Song BX, Sun HL, Zhang XL, Gu BX (1996) Study on aestivating habit of sea cucumber Apostichopus japonicus Selenka. II. Ecological characteristic of aestivation. J Fish Sci China 3:49-57

Li BQ, Yang HS, Zhang T, Zhou Y (2002) Effects of temperature on respiration and excretion of sea cucumber Apostichopus japonicus. Oceanol Limnol Sin 33:182-187

Liao Y (1997) Fauna Sinica: Phylum Echinodermata, Class Holothuroidea. Science Press, Beijing

Liu GB (2008) Artificial breeding of thermaltolerant strain of sea cucumber. Doctoral thesis, Institute of Oceanology, Chinese Academy of Sciences, Qingdao (in Chinese with English abstract)

Liu YH, Li FX, Song BX, Sun HL, Zhang XL, Gu BX (1996) Study on aestivating habit of sea cucumber Apostichopus japonicus. I. Ecological characteristic of aestivation. J Fish Sci China 3:41-48

Lü ZC, Wan FH (2008) Differential gene expression in whitefly (Bemisia tabaci) B-biotype females and males under heat-shock condition. Comp Biochem Physiol D 3: 257-262

Lu KY, Sung HJ, Liu CL, Sung HH (2009) Differentially enhanced gene expression in hemocytes from Macrobrachium rosenbergii challenged in vivo with lipopolysac-

Editorial responsibility: Judith Grassle,

New Brunswick, New Jersey, USA charide. J Invertebr Pathol 100:9-15

> Lund SG, Ruberté MR, Hofmann GE (2006) Turning up the heat: the effects of thermal acclimation on the kinetics of hsp70 gene expression in the eurythermal goby, Gillichthys mirabilis. Comp Biochem Physiol A 100:435-446

> Monari M, Matozzo V, Foschi J, Cattani O, Serrazanetti GP, Marin MG (2007) Effects of high temperatures on functional responses of haemocytes in the clam Chamelea gallina. Fish Shellfish Immunol 22:98-114

Nakano K, Iwama GK (2002) The 70-kDa heat shock protein response in two intertidal sculpins, Oligocottus maculosus and $O$. snyderi: relationship of hsp70 and thermal tolerance. Comp Biochem Physiol A 133:79-94

> Ortiz-Pineda PA, Ramírez-Gómez F, Suárez-Castillo EC, García-Ararrás JE (2009) Gene expression profiling of intestinal regeneration in the sea cucumber. BMC Genomics 10: 262-283

Parker WD, Mahr NJ, Filley CM, Parks JK, Hughes D, Young DA (1994) Reduced platelet cytochrome c oxidase activity in Alzheimer's disease. Neurology 44:1086-1090

Picard D (2002) Heat-shock protein90: a chaperone for folding and regulation. Cell Mol Life Sci 59:1640-1648

> Queitsch C, Sangster TA, Lindquist S (2002) Hsp90 as a capacitor of phenotypic variation. Nature 417:618-624

> Ramírez-Gómez F, Ortíz-Pineda PA, Rojas-Cartagena C, Suárez-Castillo EC, García-Ararrás JE (2008) Immunerelated genes associated with intestinal tissue in the sea cucumber Holothuria glaberrima. Immunogenetics 60: $57-71$

- Rast JP, Pancer Z, Davidson EH (2000) New approaches towards an understanding of deuterostome immunity. Curr Top Microbiol Immunol 248:3-16

Shigenaga MK, Hagen TM, Ames BN (1994) Oxidative damage and mitochondrial decay in aging. Proc Natl Acad Sci USA 91:10771-10778

St-Pierre J, Boutilier RG (2001) Aerobic capacity of frog skeletal muscle during hibernation. Physiol Biochem Zool 74: 390-397

Sun Y, MacRae TH (2005) Small heat shock proteins: molecular structure and chaperone function. Cell Mol Life Sci 62: 2460-2476

Sun W, Montagu MV, Verbruggen N (2002) Small heat shock proteins and stress tolerance in plants. Biochim Biophys Acta 1577:1-9

Wang WB, Li AH (2002) The effect of environmental stress on fish immune system. J Fish China 26:368-374

- Wang FY, Yang HS, Gao F, Liu GB (2008) Effects of acute temperature or salinity stress on the immune response in sea cucumber, Apostichopus japonicus. Comp Biochem Physiol A 151:491-498

Yang HS, Zhou Y, Zhang T, Yuan XT, Li XX, Liu Y, Zhang FS (2006) Metabolic characteristics of sea cucumber Apostichopus japonicus Selenka during aestivation. J Exp Mar Biol Ecol 330:505-510

Submitted: August 9, 2010; Accepted: December 20, 2010 Proofs received from author(s): February 19, 2011 